\title{
Pertumbuhan Mikroalga Chlamydomonas dalam Medium Beneck dan Air Tanah yang Mengandung Insektisida Berbahan Aktif Klorpirifos
}

\section{Growth of Chlamydomonas Microalgae in Beneck and Soil Water Media Which Contain Chlorpiriphos Insecticide}

\author{
M. Kurniasih, N.B. Prihantini \& E. Nurtiyani \\ Jurusan Biologi Fakultas Matematika dan Ilmu Pengetahuan Alam \\ Universitas Indonesia, Kampus UI Depok 16424
}

\begin{abstract}
The research of insecticide effect to the growth of genus Chlamydomonas had been done. Research was experimental study with block random design to 9 concentrations of chlorpiriphos containing insecticide in Beneck and soil water media i.e. 0 (control), 0.05, $0.10,0.15,0.20,0.25,0.30,0.35$, and $0.40 \%$. Observations were done for 35 days. Friedman test showed that there were some effects of media and insecticide concentrations on cell numbers of Chlamydomonas $(\mathrm{cell} / \mathrm{ml})$ in culture $(p>0.05)$. Dunnets test showed that mean of cell numbers of Chlamydomonas (cell/ml) differ (on p>0.05) and very differ (on p>0.01) on every concentrations in Beneck and soil water media. Insecticide could reduced the cell size of Chlamydomonas, yet increased the number of cells on 0.05--0.30\% concentrations in Beneck medium, and 0.05--0.20\% concentrations in soil water medium. On peak culture, insecticide with $0.10 \%$ concentration produced the highest cell numbers i.e. 21,179,167 cell/ml in Beneck medium, and 4,087,500 cell/ml in soil water medium.
\end{abstract}

Key words: Chlamydomonas, chlorpiriphos containing insecticide

Diterima: 16 September 2002, disetujui 14 Desember 2002

\section{Pendahuluan}

Klorpirifos adalah prototipe dari asam tiofosfat yang merupakan salah satu bahan aktif dari insektisida organofosfat. Klorpirifos bersifat sebagai racun kontak berbentuk kristal putih yang dipergunakan untuk mengendalikan antara lain serangga Atherigana exigua, Agromyza phaseoli, Agrotis sp. (Nayar et al. 1981; Baehaki 1993). Formula empiris dari klorpirifos adalah $\mathrm{C}_{9} \mathrm{H}_{11} \mathrm{C}_{11} 3 \mathrm{NO}_{3} \mathrm{PS}$ (Nayar et al. 1981).

Penggunaan insektisida tersebut ternyata menimbulkan permasalahan bagi lingkungan. Klorpirifos memiliki kelarutan yang sangat rendah dalam air $\left(0,0002 \mathrm{~g} / 100 \mathrm{~g} \mathrm{H}_{2} \mathrm{O}\right)$, tetapi mudah larut dalam pelarut organik (Nayar et al. 1981). Sifat tersebut menyebabkan terakumulasinya klorpirifos dalam jaringan organisme yang kemudian mengakibatkan terjadinya biomagnifikasi. Selain itu klorpirifos relatif sulit dihidrolisis dan dioksidasi, sehingga keberadaannya di lingkungan relatif stabil (Nayar et al. 1981).

Klorpirifos dapat dihidrolisis menjadi 3,5,6 trikloro-2 piridinol (Nayar et al. 1981) dengan bantuan beberapa variabel lingkungan seperti suhu, $\mathrm{pH}$ dan keberadaan mikroorganisme seperti bakteri yang telah lama diketahui memiliki kemampuan mengurai senyawa berbahaya dalam insektisida. Selain bakteri, beberapa mikroalga juga diketahui memiliki kemampuan yang serupa (Wright 1978).

Mikroalga yang memiliki kemampuan dalam mengurai senyawa insektisida harus memiliki daya toleransi yang tinggi sehingga mampu hidup, tumbuh dan berkembang dengan baik pada lingkungan yang tercemar insektisida. Chlamydomonas diketahui sebagai 
salah satu dari marga mikroalga yang toleran terhadap polutan (Walsh \& Merrill 1984), karena kemampuannya untuk hidup dalam air yang tercemar oleh bahan-bahan organik (Van den Hoek et al. 1995). Chlamydomonas memiliki fase dorman dengan membentuk lapisan gelatin sebagai alat proteksi diri terhadap kondisi lingkungan yang tidak menguntungkan baginya. Selama dalam fase dorman Chlamydomonas masih dapat bereproduksi secara aseksual (Kumar \& Singh 1979).

Insektisida dapat meningkatkan maupun menurunkan aktivitas fotosintetik pada mikroalga, dan hal tersebut terkait dengan pengambilan ${ }^{14} \mathrm{C}$ yang terkandung dalam insektisida. Beberapa mikroalga mampu mengakumulasi kandungan insektisida. Disamping itu beberapa mikroalga juga memiliki kemampuan untuk mengurai senyawa insektisida dengan memutus cincin aromatik dan memanfaatkan kendungan ${ }^{14} \mathrm{C}$ nya (Wright 1978). Insektisida dengan konsentrasi tinggi dapat menghambat proses pengambilan ${ }^{14} \mathrm{C}$, sebaliknya insektisida dengan konsentrasi rendah meningkatkan pengambilan ${ }^{14} \mathrm{C}$ yang akan berdampak peningkatan jumlah sel mikroalga (Mc Ewen \& Stephenson 1979).

Mikroalga selain memanfaatkan ${ }^{14} \mathrm{C}$ sebagai sumber karbon, ternyata juga dapat memanfaatkan unsur lain seperti fosfor $(\mathrm{P})$. Pemanfaatan unsur $\mathrm{P}$ dalam insektisida organofosfat oleh mikroalga dimulai dengan pemecahan struktur molekul kompleks oleh suatu enzim tertentu seperti asam fosfatase dan alkalin fosfatase. Hasilnya berupa molekul sederhana yang tidak bersifat racun yang dapat digunakan sebagai sumber nutrisi (Subramanian et.al. 1994).

Penelitian ini dilakukan dengan tujuan untuk mengetahui pengaruh insektisida berbahan aktif klorpirifos yang ditambahkan pada medium Beneck and air tanah terhadap pertumbuhan mikroalga Chlamydomonas galur Subang, Jawa Barat. Hasil penelitian menunjukkan bahwa Chlamydomonas galur Subang memiliki kemampuan hidup, tumbuh dan berkembang pada medium mengandung insektisida berbahan aktif klorpirifos, dengan konsentrasi tertentu.

\section{Metode Penelitian}

\section{Lokasi dan waktu penelitian:}

Penelitian dilakukan di ruang kultur alga, laboratorium Taksonomi Tumbuhan Jurusan Biologi FMIPA UI pada bulan September sampai dengan Oktober 2001.

\section{Bahan dan cara kerja:}

Biakan Chlamydomonas yang digunakan berasal dari koleksi laboratorium Taksonomi Tumbuhan Jurusan Biologi FMIPA-UI yang disolasi dari kolam alga pengolahan limbah karet hasil buangan pabrik karet di Subang Jawa Barat.

Medium Beneck perlakuan (Beneck + insektisida) dan air tanah perlakuan (air tanah + insektisida) sebanyak $45 \mathrm{ml}$ dengan berbagai konsentrasi, yaitu: 0,$05 ; 0,10 ; 0,15 ; 0,20 ; 0,25$; 0,$30 ; 035 ; 0,40 \%$; dan medium kontrol terdiri atas medium Beneck dan medium air tanah tanpa penambahan insektisida. Insektisida yang digunakan adalah insektisida berbahan aktif klorpirifos dengan formulasi Dursban 20EC mengandung $200 \mathrm{~g}$ klorpirifos $/ \mathrm{l}$.

Penelitian bersifat eksperimental dengan rancangan acak berblok (Block Random Design). Jumlah sampel 18, yaitu 8 sampel medium Beneck + insektisida dengan konsentrasi yang berbeda, 8 sampel medium air tanah + insektisida dengan konsentrasi yang berbeda, dan 2 medium kontrol (Beneck dan air tanah).

Sebanyak $5 \mathrm{ml}$ kultur Chlamydomonas berkerapatan $165.625 \mathrm{sel} / \mathrm{ml}$ yang telah berumur 4 minggu dimasukkan ke dalam $45 \mathrm{ml}$ medium kontrol dan medium perlakuan. Setelah itu dilakukan penghitungan jumlah sel setiap 24 jam selama 35 hari terhadap 3 tetes kultur $(0,12 \mathrm{ml})$ yang dikocok hingga homogen. Penghitungan dilakukan dengan menggunakan pipet Thoma untuk sel darah putih dan kamar hitung Improved Neubauer (Adil 1997). Jumlah sel Chlamydomonas yang diperoleh merupakan rerata jumlah sel dari dua kamar hitung. Berdasarkan data jumlah sel dilakukan penghitungan kerapatan sel dan laju pertumbuhan. Jumlah sel dalam $1 \mathrm{ml}$ larutan adalah larutan adalah $\mathrm{n} \times \mathrm{p} \times\left(1 / 0,4 \mathrm{~mm}^{3}\right) \mathrm{x}$ 
$\left(1000 \mathrm{~mm}^{3} / 1 \mathrm{~cm}^{3}\right)=\mathrm{n} \times \mathrm{p} \times 2500$, dengan $\mathrm{n}$ adalah jumlah sel Chlamydomonas, dan $p$ adalah tingkat pengenceran yang digunakan pada pipet Thoma (Adil 1997). Penghitungan laju pertumbuhan menggunakan rumus Hirata, yaitu $\left(\log 19 \mathrm{~N} / \mathrm{N}_{0}\right) /\left(\mathrm{t}-\mathrm{t}_{0}\right)$ x 3,22, dengan $\mathrm{N}$ adalah jumlah sel pada waktu $\mathrm{t}, \mathrm{N}_{0}$ adalah jumlah sel pada waktu $t_{0}$ dan 3,22 merupakan konstanta (Amin \& Amini 1992).

\section{Hasil Dan Pembahasan}

\section{a. Kerapatan sel}

Kerapatan Chlamydomonas (sel/ml) pada medium Beneck dan air tanah pada saat inokulasi adalah $165.625 \mathrm{sel} / \mathrm{ml}$. Rerata kerapatan Chlamydomonas (sel/ml) pada medium Beneck pada saat puncak (peak) ditunjukkan oleh Gambar 1.

Kerapatan Chlamydomonas (sel/ml ) dalam medium Beneck dan air tanah pada saat peak jika dibandingkan dengan kerapatan Chlamydomonas $(\mathrm{sel} / \mathrm{ml})$ pada saat inokulasi sebesar $165.625 \mathrm{sel} / \mathrm{ml}$ menunjukkan adanya pertumbuhan Chlamydomonas, yang menandakan bahwa Chlamydomonas mampu beradaptasi terhadap semua konsentrasi insektisida pada medium Beneck dan air tanah. Kerapatan Chlamydomonas (sel/ml) pada saat peak pada medium Beneck dengan konsentrasi insektisida $0,05--0,30 \%$, dan medium air tanah dengan konsentrasi insektisida 0,05--0,20\% lebih tinggi dari medium kontrol Beneck dan air tanah. Hal tersebut menandakan kemungkinan terjadinya pemanfaatan insektisida oleh Chlamydomonas.

Adanya gugusan cincin aromatik yang terdapat dalam insektisida menyebabkan insektisida bersifat racun, dan dapat mengganggu proses metabolisme sel. Semakin tinggi konsentrasi insektisida, maka semakin besar efek racunnya dan menyebabkan kerapatan Chlamydomonas (sel/ml) akan semakin rendah.

Kerapatan sel yang terendah terdapat pada konsentrasi insektisida yang tinggi, yaitu pada konsentrasi insektisida $0,40 \%$ pada medium Beneck dan konsentrasi insektisida 0,35\% pada medium air tanah. Sedangkan kerapatan sel tertinggi dijumpai pada konsentrasi insektisida rendah, yaitu pada konsentrasi insektisida $0,10 \%$ pada medium Beneck maupun medium air tanah. Insektisida dengan konsentrasi $0,10 \%$ mungkin dapat dimanfaatkan Chlamydomonas sebagai nutrisi, yang diduga sesuai bagai Chlamydomonas, sehingga mampu tumbuh maksimal. Nilai kerapatan tersebut sejalan dengan penampakan warna kultur paling pekat pada konsentrasi insektisida $0,10 \%$, dan warna kultur yang paling muda pada konsentrasi insektisida $0,40 \%$.

Uji Friedman terhadap rerata kerapatan sel selama pengamatan menunjukkan adanya pengaruh medium dan konsentrasi insektisida terhadap kerapatan sel Chlamydomonas. Uji perbandingan berganda terhadap kerapatan sel pada medium kontrol Beneck dan air tanah menunjukkan adanya perbedaan yang sangat nyata $(p>0,01)$ dan nyata $(p>0,05)$ terhadap medium Beneck dan air tanah dengan konsentrasi insektisida 0,$05 ; 0,10 ; 0,15 ; 0,30$; 0,35 ; dan $0,40 \%$. Sedangkan uji perbandingan berganda antar konsentrasi insektisida menunjukan perbedaan yang sangat nyata $(\mathrm{p}>0,01)$, dan nyata $(\mathrm{p}>0,05)$ pada semua konsentrasi insektisida.

Penambahan insektisida dengan konsentrasi rendah dapat memicu pertumbuhan sel Chlamydomonas, karena kandungan ${ }^{14} \mathrm{C}$ dan $\mathrm{P}$ yang terdapat dalam insektisida mungkin berfungsi sebagai tambahan nutrisi bagi sel Chlamydomonas. Ikatan cincin aromatik berupa rantai karbon siklik dapat diputuas olah Chlamydomonas dengan melepaskan komponen ekstraselulernya. Ikatan gugus fosfat dapat dipecah oleh enzim asam fosfatase dan enzim alkalin fosfatase yang merupakan komponen seluler yang dikeluarkan oleh mikroalga melalui membran sel (Hellebust 1974; Subramanian et al. 1994). Karbon-14 yang diserap oleh Chlamydomonas melalui proses difusi dalam bentuk $\mathrm{CO}_{2}$, selanjutnya akan masuk ke dalam siklus Calvin yang merupakan reaksi gelap pada proses fotosintesis. Hasil akhir dari proses tersebut adalah glukosa akan digunakan untuk pertumbuhan sel Chlamydomonas. Pada proses respirasi, glukosa akan dipecah menjadi piruvat kemudian didekarboksilasi menghasilkan asetil ko-A yang akan melalui siklus Krebs untuk 
memproduksi ATP. ATP dapat dipergunakan oleh Chlamydomonas salah satunya untuk pertumbuhan dan perkembangan sel. Kandungan unsur $\mathrm{P}$ yang terdapat dalam insektisida berguna untuk pembentukan ATP pada proses fotofosforilasi, yang akan digunakan untuk mereduksi $\mathrm{CO}_{2}$ pada siklus Calvin. Selain itu unsur $\mathrm{P}$ secara tidak langsung juga berkaitan dengan perkembangan pigmen asesori pada mikroalga.

\section{b. Kurva pertumbuhan}

Kurva pertumbuhan mikroalga Chlamydomonas pada masing-masing kultur menunjukkan pola pertumbuhan yang berbedabeda (Gambar $2 \& 3$ ). Pola pertumbuhan pada kurva sejalan dengan laju pertumbuhan pada kultur Chlamydomonas. Nilai laju pertumbuhan tersebut dapat digunakan untuk menentukan fase-fase yang dialami oleh kultur Chlamydomonas. Awal fase log dapat ditentukan berdasarkan kenaikan nilai laju pertumbuhan. Fase log akan berakhir dan kultur memasuki fase stasioner yang ditunjukkan oleh nilai laju pertumbuhan yang tertinggi.

Berdasarkan nilai laju pertumbuhan, diketahui bahwa pada konsentrasi insektisida rendah, kultur Chlamydomonas mengalami fase lag yang singkat. Sebaliknya pada konsentrai insektisida tinggi, kultur Chlamydomonas mengalami fase lag yang sangat panjang. Misalnya pada konsentrasi insektisida $0,05 \%$ pada medium Beneck fase $\log$ dimulai pada hari ke-5, sedangkan pada konsentrasi insektisida $0,40 \%$ fase $\log$ baru dimulai pada hari ke-30. Fase lag menandakan waktu adaptasi yang dibutuhkan Chlamydomonas untuk dapat memanfaatkan kandungan ${ }^{14} \mathrm{C}$ dan $\mathrm{P}$ yang terdapat dalam insektisida.

$$
\text { Laju pertumbuhan kultur }
$$

Chlamydomonas pada hari ke-1--7 pada medium air tanah lebih tinggi jika dibandingkan dengan medium Beneck. Hal tersebut terkait dengan kebutuhan akan unsur P. Asam fosfatase dan alkalin fosfatase akan disintesis pada saat sel mengalami defisiensi unsur P. Pengambilan unsur P pada sel yang mengalami defisiensi akan lebih cepat dan lebih banyak jika dibandingkan dengan sel yang kebutuhannya akan unsur $\mathrm{P}$ tercukupi (Jansson 1988), dan pada air tanah yang digunakan kemungkinan kekurangan akan unsur P. Menurut Prinson et.al. pada tahun 1952 (Kuhl 1974) defisiensi dari unsur P dapat menghambat produksi berat kering, pembelahan sel, produksi $\mathrm{O}_{2}$ dari fotosintesis, dan sintesis klorofil. Defisiensi unsur $\mathrm{P}$ pada kultur Chlamydomonas pada medium air tanah dapat terlihat setelah kultur berumur lebih dari 14 hari, yang ditunjukkan oleh kultur yang berwarna kuning dan kerapatan sel yang rendah.

\section{Kesimpulan}

Berdasarkan hasil penelitian dapat disimpulkan bahwa:

1. Pada medium Beneck, kerapatan Chlamydomonas (sel $/ \mathrm{ml}$ ) tertinggi saat peak, sebesar 21.179.167 sel $/ \mathrm{ml}$, diperoleh dari konsentrasi insektisida $0,10 \%$, sedangkan kerapatan sel terendah saat peak, sebesar $520.833 \mathrm{sel} / \mathrm{ml}$, diperoleh dari konsentrasi insektisida $0,40 \%$.

2. Pada medium air tanah, kerapatan sel tertinggi saat peak, sebesar 4.087.500 sel $/ \mathrm{ml}$, diperoleh dari konsentrasi insektisida $0,10 \%$, sedangkan kerapatan sel terendah saat peak, sebesar $338.750 \mathrm{sel} / \mathrm{ml}$, yang diperoleh dari konsentrasi insektisida $0,35 \%$.

\section{Daftar Pustaka}

Adil, I.M. 1997. Penuntun Praktikum Fisiologi Hewan. Jurusan Biologi. FMIPA UI, Depok.

Amin, M. \& S. Amini. 1992. Rasionalisasi Pupuk Komersil pada Budidaya Fitoplankton.

Prosiding Lokakarya Penelitian dan Studi Khusus: 528-543.

Baehaki.1993.Insektisida Pengendalian Hama Tanaman. Angkasa, Bandung. 
Hellebust, J.A. 1974. Extracellular Products. In: Stewart. 9ed.). Algal Physiology and Biochemistry.University of California Press, California: 838-863.

Jansson, M. 1988. Phosphate uptake and utilization by bacteria and microoalgae. In: Persson, G. \& M. Jansson. (eds.). 1988. Phosphorus in freshwater ecosystem. Kluwer Academic Publishers, Dordrecth: 177-189.

Kuhl, A. 1974. Phosphorus. In: Stewart, W.D.P. (ed.). 1974. Algal Physiology and Biochemestry. University of California Press, California: 636-654.

Kumar, H.D. \& H.N. Singh. 1979. A Textbook on Algae. Macmillan Press Ltd., London.

Mc. Ewen, F.l. \& G.r. Stephenson. 1979. The Use and Significance of Pesticides in the Environment. John Willey \& Sons, New York.

Nayar, K.K., T.N. Ananthakrishnan \& B.V. David. 1982. General and Applied Entomology. Tata McGraw-Hill Publishing Company Limited, New Delhi.
Subramanian, G., S. Sekar \& S. Sampoornam.1994. Biodegradation and Utilization of Organophosphorus Pesticide by Cyanobacteria. International Biodeterioration \& Biodegradation 33: 129-143.

van den Hoek, C., D. G. Mann, \& H. M. Jahns. 1995. Algae. Anintroduction to Phycology. Cambridge University Press, Melbourne.

Vashishta, B.R. 1978. Botany for Degree Students: Algae. $7^{\text {th }}$ ed. S. Chand \& Comp. Ltd., Ram Nagar.

Walsh, G.E. \& R.G. Merill. 1984. Algal Bioassays of Industrial and Energy Process Effluents. In: Shubert. L.E. (ed.). 1984. Algae as Ecological Indicators. Academic Press Inc., London: 329-360.

Wright, S.J.L. 1978. Interaction of Pesticides With Microalgae. In: Wrigth, S.J. \& I.R. 1978. Pesticides Microbiology: microbial Aspects of Pesticide Behavior in the Environment. Academic Press, London: 535-590.

Zar, J.H. 1974. Biostatistical Analysis. Prentice-Hall, inc., London

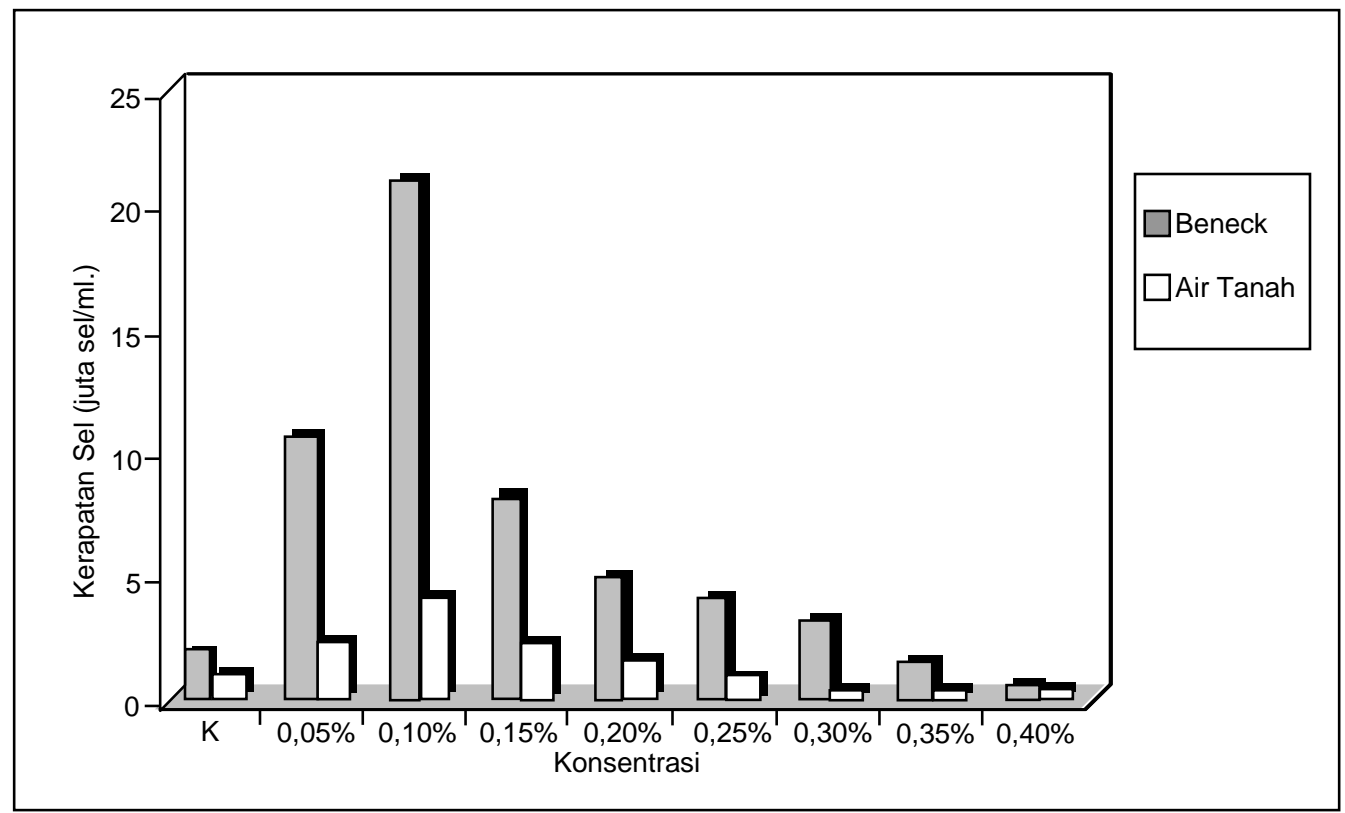

Gambar 1. Diagram Batang Kerapatan sel Chlamydomonas pada saat peak pada 8 konsentrasi insektisida dan kontrol $(K)$. 


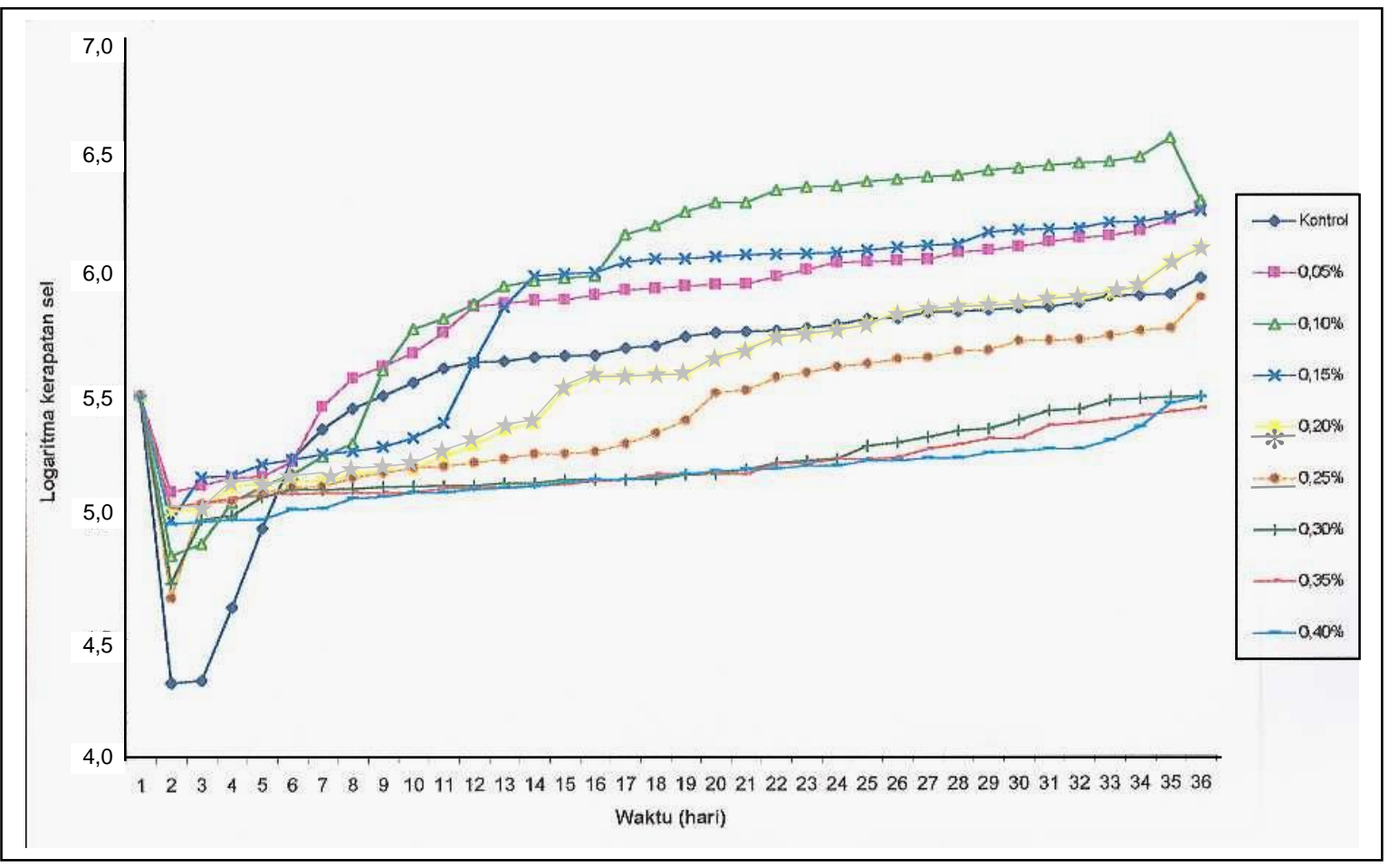

Gambar 2. Kurva pertumbuhan sel Chlamydomonas dalam medium Beneck selama 35 hari pengamatan

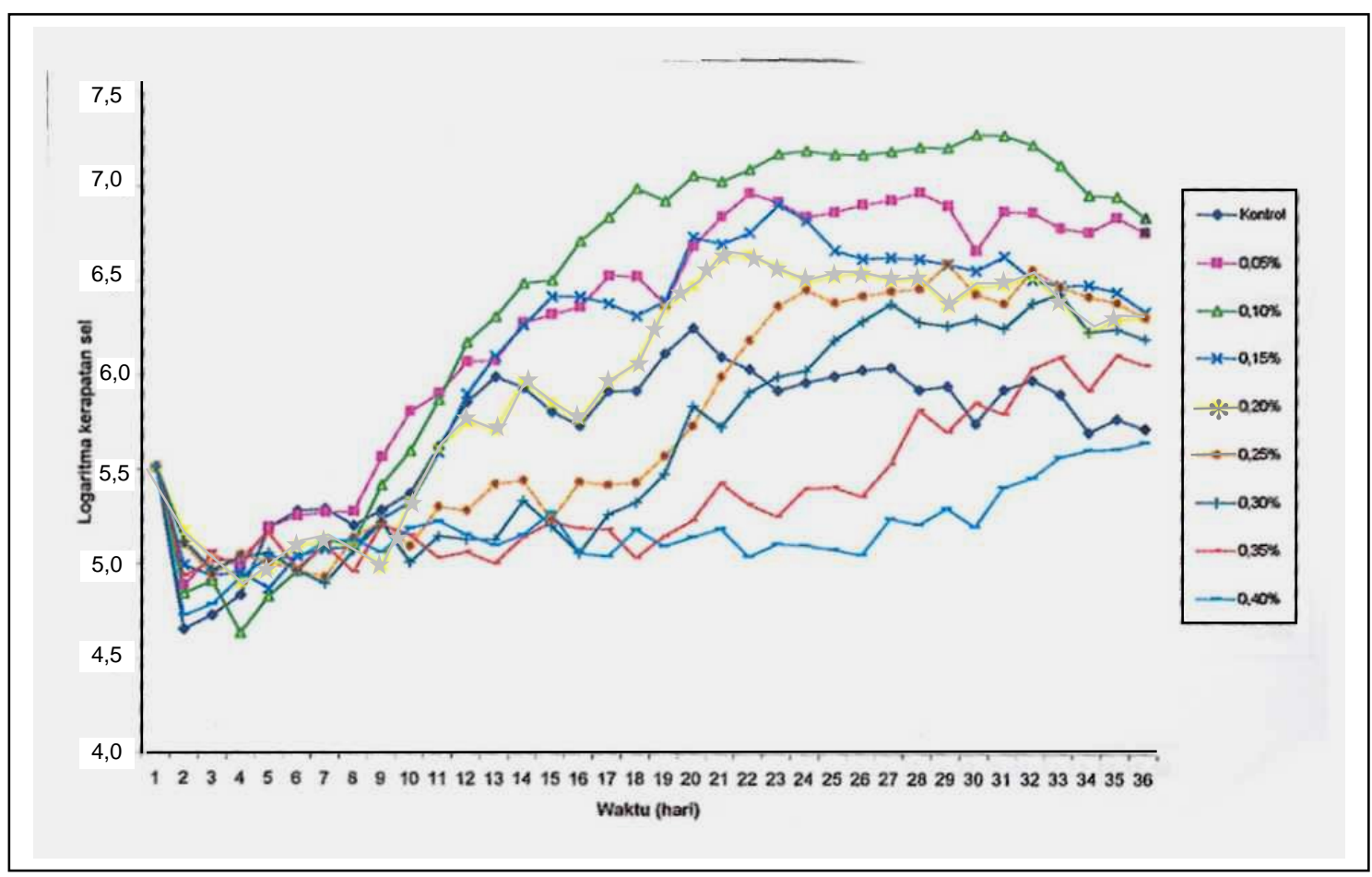

Gambar 3. Kurva pertumbuhan sel Chlamydomonas dalam medium air tanah selama 35 hari pengamatan 
M. Kurniasih., et al.

Biota Vol. VIII (1), Februari 2003 